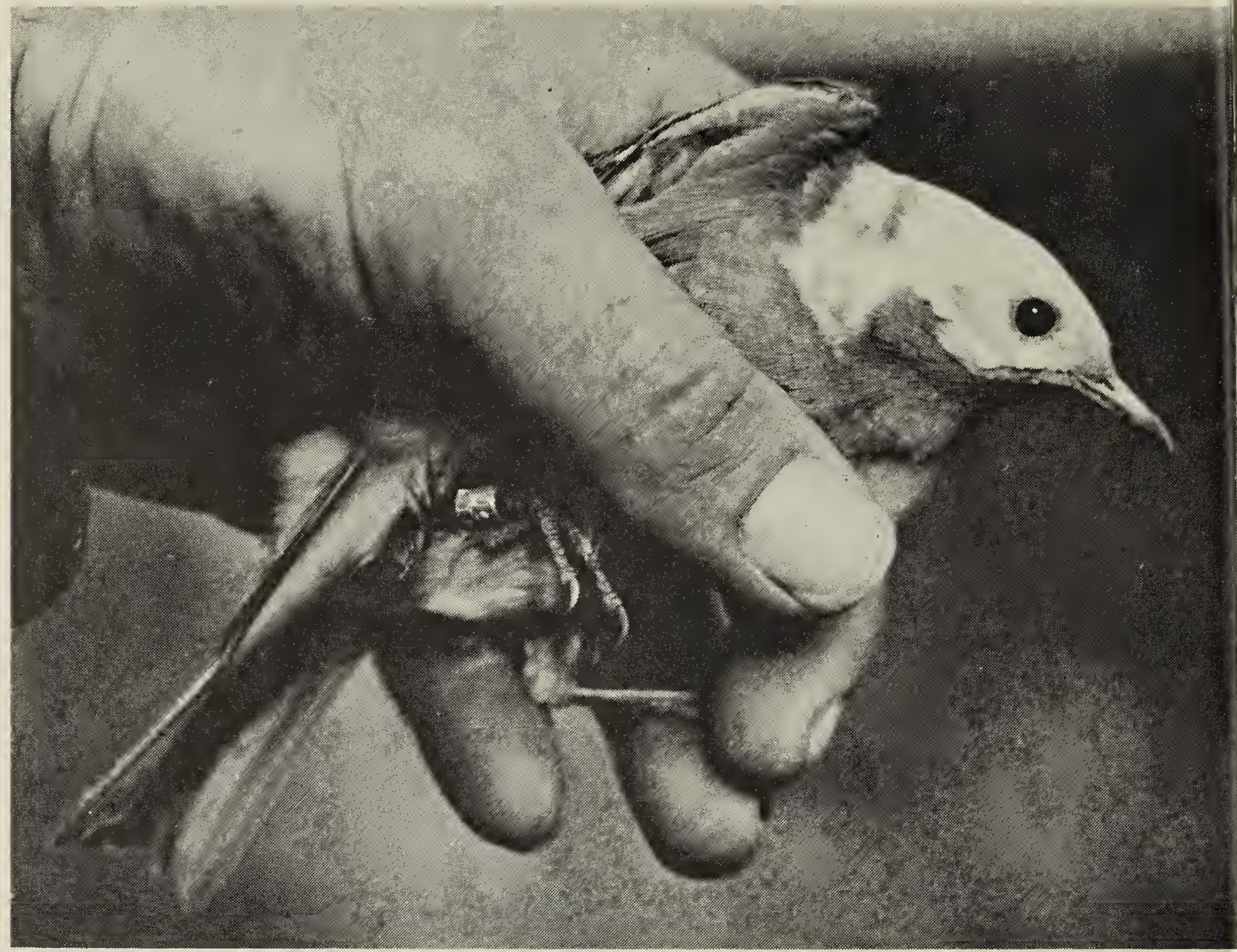

Lorne Scott White-headed female Mountain Bluebird, Indian Head, Saskatchewan. May 26, 1974.

the young bluebirds have always died in the nest until this year when one young bluebird was fledged along with five Tree Swallows.

Since 1963, 1,800 nest boxes have been set out along the Indian Head bluebird trail. A total of 4,000 bluebirds and 8,000 Tree Swallows have been banded since 1969. Several hundred more bluebirds and swallows that were not banded have been fledged from the houses.

I hope to set out another 200 houses next spring but due to the time and expense involved I do not expect to carry out an extensive banding program as I have done in the past.

\section{SASKATOON BLUEBIRD TRAIL - 1974}

by DONALD S. HOUSTON*

This year, our success with the bluebird house trail was again good. We relocated a number of boxes that had been used by House Sparrows, into proven bluebird territory, and added a few more (including seven contributed by Leo Smith of Toronto) to bring the total in our main study area to 233 houses. Of these, eight were damaged and empty and only seven were intact and unoccupied - for a 94\% occupancy rate.

We had 54 nestboxes used by Moun-

*863 University Drive,

Saskatoon, Saskatchewan.

S7N 0J8. 
tain Bluebirds, up from 35 last year (and compared to $3,8,12$ and 25, respectively, in the first 4 years). In addition, we had our first female Eastern Bluebird, mated to a male Mountain Bluebird, producing five healthy hybrid young. Due to a late spring and heavy spring rains, many nests were deserted and the average brood size for bluebirds was only 4.73, yet we banded a record 183 young Mountain Bluebirds plus the five hybrids mentioned.

Our Tree Swallows did well this year with an average brood size of 5.44 when banded. With increasing numbers of bluebirds and House Wrens, the latter up from a previous maximum of two to eight this year, the number of boxes used by Tree Swallows was down to 132 this year. House Sparrows, fortunately, dropped from 52 to 45 boxes.

Twenty-one boxes were used by two or more species during the season. One pair of Tree Swallows successfully raised five young and simultaneously fledged a young bluebird from an egg left by a Mountain Bluebird that had occupied the box before the swallows took over. In total, the Saskatoon Junior Natural History Society is pleased with results for the past 6 years and we look forward to a further increase in bluebird occupancy in 1975 .

\section{LANGHAM, SASKATCHEWAN BLUEBIRD PROJECT - 1974}

\section{by JACK KARGUT*}

This spring instead of the usual 10 boxes to the mile, we erected 12 boxes in one half mile as an experiment. The results speak for themselves: four pairs of Mountain Bluebirds, eight pairs of Tree Swallows and one pair of House Wrens, including a pair of bluebirds that followed a swallow nesting - all in a half mile!

*Box 92

Langham, Salskatchewan

SOK 2LO
Efforts to date:

Nesting boxes added - New

-Replacements 21

Total boxes erected (1971-1974) 452

Additional area covered 1974:

No. 5 Highway, Denholm to

Battleford completed.

Sandhills area extended to Asquith grid-road.

Grid-road north to correction line (approx. 6 miles).

Park Municipal Pasture (approx. 5 miles).

Upper approach to Borden bridge.

South and west along N. Saskatchewan River (approx. 5 miles).

1974 Results:

Mountain Bluebird

93 pairs

(440 eggs and young)

Tree Swallow 268 pairs

(1459 eggs and young)

House Sparrow

27 pairs

House Wren

10 pairs

Flicker

Starling

2 pairs

Vacant

1 pair

Boxes unaccounted for

31

20

\section{WESTERN TANAGER SIGHTING IN MANITOBA}

\author{
by CALVIN CUTHBERT*
}

On June 26, 1973, while participating in Breeding Bird Surveys in the Carberry Spruce Woods area of Manitoba I had the good fortune to observe a male Western Tanager.

At 6:30 a.m. I was about to complete the last grid line of a 20-acre plot located 20 miles southeast of Carberry. A series of hoarse warbling notes, however, coming from inside a nearby stand of mature white spruce caught my attention. The song was unfamiliar to me and, as I had not heard

${ }^{*}$ R.R. 1, Box 59,

Portage La Prairie, Manitoba. 